COSTING:Journal of Economic, Business and Accounting

Volume 4 Nomor 2, Juni 2021

e-ISSN : 2597-5234

IMMEKpe

\title{
PENGARUH LIKUIDITAS, PROFITABILITAS, STRUKTUR MODAL, UKURAN PERUSAHAAN DAN KEBIJAKAN DIVIDEN TERHADAP NILAI PERUSAHAAN PERUSAHAAN MANUFAKTUR YANG TERDAFTAR DI BURSA EFEK INDONESIA
}

\section{THE EFFECT OF LIQUIDITY, PROFITABILITY, CAPITAL STRUCTURE, FIRM SIZE AND DIVIDEND ON FIRM VALUE OF MANUFACTURING COMPANIES LISTED IN INDONESIA STOCK EXCHANGE}

\author{
Annisa Nauli ${ }^{1}$, Calvin Halim², Sonia $^{3}$ \\ Universitas Prima Indonesia ${ }^{1,2,3}$ \\ calvin.halim.940@gmail.com²
}

\begin{abstract}
Firm value is one of the criteria used by investors in making decisions to invest in a company where Firm value is often associated with share prices. The purpose of this research is to determine the effect of Capital Structure (DER), Liquidity (QR), Profitability (ROA), Dividends (DPR), and Firm Size (Total Assets) on the Firm Value. This type of research is quantitative descriptive with secondary data, the selection of research samples using purposive sampling techniques, and testing methods with multiple linear regression analysis method. The population in this research were 167 manufacturing companies listed on the IDX during the period 2016 - 2019. Based on the results of the study, it can be concluded that simultaneously the Capital Structure (DER), Liquidity (QR), Profitability (ROA), Dividend (DPR), and Firm Size (total assets) have a simultaneous and positive effect. While partially, only Dividend (DPR) has a positive effect on Firm Value, while Profitability (ROA) have a negative effect on Firm Value; Capital Structure (DER), Liquidity (QR) and Firm Size (Total Assets) have no effect and is insignificant on Firm Value.
\end{abstract}

Keywords : Capital Structure, Liquidity, Profitability, Dividends, Firm Size

\begin{abstract}
ABSTRAK
Nilai perusahaan adalah salah satu kriteria yang dipakai investor dalam pengambilan keputusan untuk berinvestasi di suatu perusahaan dimana nilai perusahaan sering dikaitkan sengan harga saham. Tujuan dari penelitian ini adalah untuk melihat pengaruh dari Struktur Modal (DER), Likuiditas (QR), Profitabilitas (ROA), Dividen (DPR), dan Ukuran Perusahaan (Total Aktiva) terhadap nilai perusahaan. Jenis penelitian ini adalah deskriptif kuantitatif dengan sumber data sekunder, pemilihan sampel penelitian dengan menggunakan teknik purposive sampling, dan metode pengujian dengan metode analisis regresi linier berganda. Jumlah populasi pada penelitian ini adalah 167 perusahaan manufaktur yang terdaftar di BEI selama periode 2016 - 2019. Berdasarkan Hasil Penelitian dapat disimpulkan bahwa secara simultan Struktur Modal (DER), Likuiditas (QR), Profitabilitas (ROA), Dividen (DPR), dan Ukuran Perusahaan (total aktiva) berpengaruh simultan dan positif. Sedangkan secara parsial, hanya Dividen (DPR) yang
\end{abstract}


berpengaruh positif terhadap Nilai Perusahaan sedangkan Struktur Modal (DER) berpengaruh negatif terhadap Nilai Perusahaan; Profitabilitas (ROA), Likuiditas (QR) dan Ukuran Perusahaan (Total Aktiva) tidak berpengaruh dan tidak signifikan terhadap Nilai Perusahaan.

Kata Kunci : Struktur Modal, Likuiditas, Profitabilitas, Dividen, Ukuran Perusahaan

\section{PENDAHULUAN}

Kinerja perusahaan merupakan salah satu unsur yang penting dari berbagai aspek untuk mengukur nilai perusahaan. Investor dapat mengambil keputusan untuk berinvestasi dengan melihat tingkat keberhasilan sebuah perusahaan yang sering dikaitkan dengan harga saham, sehingga akvitas harga saham sebuah perusahaan dapat ditentukan oleh permintaan dan penawaran terhadap saham perusahaannya. Kondisi perusahaan juga merupakan salah satu unsur yang penting untuk mengukur pergerakan harga saham tersebut. Meningkatnya nilai perusahaan merupakan tujuan jangka panjang perusahaan, adapun juga tujuan jangka pendek yaitu untuk mendapatkan laba semaksimal mungkin untuk mencapai tujuan.

Likuiditas adalah kemampuan perseorangan atau kelompok untuk melunasi hutang yang harus segera dibayarkan menggunakan harta lancarnya. Semakin tinggi likuiditas suatu perusahaan, maka kinerja perusahaan tersebut akan dianggap semakin bagus dan dengan mudah memperoleh kepercayaan dari pihak luar perusahaan.

Profitabilitas digunakan untuk mengetahui kemampuan suatu perusahaan dalam memperoleh laba (profit) dari penjualan, harta, dan modal. Semakin tinggi nilai rasio tersebut, maka semakin baik pula kondisi keuangan perusahaan tersebut.
Struktur modal adalah perimbangan jumlah hutang jangka pendek yang bersifat tetap, hutang jangka panjang, saham preferen, dan saham biasa. Faktor penentu strukur modal adalah pertumbuhan aktiva, dimana pertumbuhan aktiva berpengaruh terhadap nilai dari suatu perusahaan. Semakin tingginya struktur modal, maka akan berpengaruh juga terhadap semakin tingginya nilai perusahaan.

Ukuran perusahaan adalah suatu skala pengukuran perusahaan yang dapat dilihat melalui total aktiva dan total penjualan suatu perusahaan pada setiap akhir periode tahunan, dimana semakin tinggi nilai aktiva atau penjualan suatu perusahaan, maka perusahaan tersebut memiliki nilai yang tinggi di mata investor.

Kebijakan dividen adalah pembagian laba suatu perusahaan dalam suatu periode kepada para pemegang saham sesuai persentase kepemilikannya di perusahaan tersebut. Sumber dana pembagian laba didapat dari hasil operasi perusahaan tersebut selama periode tertentu. Semakin tingginya dividen suatu perusahaan maka akan semakin berpengaruh terhadap nilai perusahaan.

Antari \& Dana (2013), suatu perusahaan harus peka terhadap penggunaan hutang karena pemakaian hutang bisa berdampak positif maupun negatif terhadap perusahaan. Hal ini juga berdampak pada menurunnya nilai perusahaan akibat tingginya penggunaan hutang dan rendahnya kemampuan perusahaan untuk mendapatkan laba. 
Struktur modal yang seharusnya adalah yang dapat mengoptimalkan kesetaraan antara risiko dan pengembalian sehingga dapat mempertahankan maupun meningkatkan harga saham. Dengan itu dalam penetapan struktur modal harus mempertimbangkan berbagai faktor yang mempengaruhinya.

Thaib \& Dewantoro (2017), likuiditas merupakan kemampuan perusahaan untuk mencapai kewajibannya dengan tepat waktu. Perusahaan yang memiliki laba yang tinggi belum tentu dapat membayar kewajibannya karena dana tidak mencukupi. Dengan memantau likuiditas suatu perusahaan pihak kreditur juga dapat memberi kritik baik atau buruknya perusahaan tersebut.

Likuiditas merupakan kemampuan perusahaan untuk membayar hutang jangka pendek. Semakin tinggi likuiditas, maka kinerjanya dianggap semakin bagus dan perusahaan dengan likuiditas yang meningkat akan lebih mudah untuk mendapatkan dukungan dari berbagai pihak.

Lubis, et.al (2017), profitabilitas merupakan sebuah faktor secara spekulatif menentukan nilai suatu perusahaan. Meningkatkan kepercayaan investor yang pada akhirnya dapat meningkatkan harga saham menjadi tinggi artinya meningkatnya nilai perusahaan. Menurunnya ketidakpercayaan ini dapat mempengaruhi harga saham menjadi turun dan nilai perusahaan semakin rendah.

Profitabilitas merupakan kemampuan suatu perusahaan untuk memperoleh laba. Profitabilitas sangatlah penting karena dapat mengukur kinerja keuangan dan sebagai panduan untuk menilai suatu perusahaan. Semakin tinggi profitabilitas, maka semakin bagus nilai perusahaan.
Putra \& Lestari (2016), kebijakan dividen merupakan pertimbangan bagaimana cara perusahaan menggunakan pendapatan apakah akan dibayar dividen atau dijadikan sebagai investasi. Kebijakan dividen sering diperkirakan seperti sinyal bagi investor untuk menilai baik buruknya suatu perusahaan, karena kebijakan dividen dapat membawa hubungan terhadap nilai perusahaan.

Kebijakan dividen adalah pertimbangan sebuah perusahaan apakah akan membayar dividen atau dijadikan sebagai investasi. Sehingga pembayaran dividen juga memiliki hubungan terhadap nilai perusahaan. Pratama \& Wiksuana (2016), ukuran perusahaan merupakan sebuah variabel estimasi dalam penentuan nilai perusahaan. Ukuran perusahaan juga disebut sebagai cerminan total harta yang dimiliki perusahaan. Semakin besar ukuran perusahaan akan mempengaruhi keputusan perusahaan dalam bagaimana penggunaan dana dapat mengoptimalkan nilai perusahaan.

Ukuran perusahaan adalah sebuah skala perusahaan yang dapat dilihat dari total harta perusahaan. Besarnya ukuran perusahaan dapat menentukan kemudahan untuk mendapatkan dana dari pasar modal.

\section{METODE PENELITIAN}

Penelitian ini dilakukan pada perusahaan manufaktur yang terdaftar di Bursa Efek Indonesia (BEI) pada rentang periode 2016-2019. Penelitian ini menggunakan data sekunder yang diambil dari website www.idx.co.id dalam bentuk laporan keuangan. Pendekatan yang dilakukan pada penelitian ini adalah pendekatan kuantitatif dan jenis penelitian deskriptif kuantitatif. 


\section{Populasi dan Sampel}

Populasi yang digunakan dalam penelitian ini terdiri dari 167 perusahaan manufaktur yang terdaftar di Bursa Efek Indonesia tahun 2016-2019. Teknik penarikan sampel yang digunakan dalam penelitian ini adalah teknik purposive sampling. Teknik ini menentukan sampel berdasarkan kriteria tertentu. Kriteria penarikan sampel dalam penelitian ini adalah sebagai berikut:

Tabel 1 Tabel Perhitungan Sampel

\begin{tabular}{clc}
\hline No & \multicolumn{1}{c}{ Kriteria } & Jumlah \\
\hline 1 & $\begin{array}{l}\text { Perusahaan manufaktur yang } \\
\text { terdaftar di BEI pada tahun } \\
2016-2019\end{array}$ & 167 \\
\hline \multirow{2}{*}{2} & $\begin{array}{l}\text { Perusahaan manufaktur yang } \\
\text { tidak menyajikan laporan } \\
\text { keuangan berturut-turut } \\
\text { selama tahun 2016-2019 }\end{array}$ & $(35)$ \\
\hline 3 & $\begin{array}{l}\text { Perusahaan manufaktur yang } \\
\text { mengalami kerugian selama } \\
\text { tahun 2016-2019 }\end{array}$ \\
\hline & $\begin{array}{l}\text { Perusahaan manufaktur yang } \\
\text { tidak membagikan dividen } \\
\text { secara berturut-turut tahun }\end{array}$ & $(49)$ \\
2016-2019 & \\
\hline Jumlah Sampel & 43 \\
\hline & Jumlah Periode & 4 \\
\hline & Jumlah Observasi & 172 \\
\hline
\end{tabular}

Sumber : Data Olahan (2020)

Total jumlah data observasi pada penelitian ini sebanyak 172 data. Untuk mengumpulkan data yang diperlukan ini dilakukan dengan cara mengambil dan mengumpulkan laporan keuangan yang berkaitan dengan perusahaan manufaktur yang terdaftar di Bursa Efek Indonesia (BEI) dan data tersebut didapatkan dari website resmi Bursa Efek Indonesia (BEI).

\section{Teknik Analisis Data}

Teknik analisis yang digunakan dalam penelitian ini yaitu uji regresi linear berganda. Setelah dilakukan uji asumsi klasik maka dilakukan uji regresi linear berganda. Analisis regresi linear berganda bertujuan untuk menguji hubungan antara beberapa variabel independen dan variabel dependen. Adapun variabel independen dalam penelitian ini yaitu Struktur Modal (X1), Likuiditas (X2), Profitabilitias (X3), Dividen (X4), dan Ukuran Perusahaan (X5) sedangkan variabel dependen dalam penelitian ini yaitu Nilai Perusahaan (Y). Model persamaan regresi dalam penelitian ini yaitu sebagai berikut :

$$
\begin{aligned}
& \mathbf{Y = \alpha}+\boldsymbol{\beta 1 X 1}+\boldsymbol{\beta 2 X 2}+\boldsymbol{\beta 3 X 3}+\boldsymbol{\beta 3 X} \mathbf{4}+ \\
& \boldsymbol{\beta 3 X 5}+\mathbf{e} \\
& \text { Keterangan : } \\
& \mathrm{Y} \quad \text { = Variabel Nilai Perusahaan } \\
& \alpha \quad=\text { Konstanta } \\
& \beta 1-\beta 5=\text { Koefisien } \\
& \mathrm{X} 1 \quad=\text { Struktur Modal } \\
& \mathrm{X} 2 \quad=\text { Likuiditas } \\
& \mathrm{X} 3 \quad=\text { Profitabilitas } \\
& \mathrm{X} 4 \quad=\text { Dividen } \\
& \mathrm{X} 5 \quad=\text { Ukuran Perusahaan } \\
& \mathrm{e} \quad=\text { Kesalahan Residual (error) }
\end{aligned}
$$

\section{Uji Normalitas}

Uji Normalitas yaitu suatu uji yang digunakan untuk memberikan pendapat apakah suatu data berdistribusi normal atau tidak. Uji normalitas yang digunakan dalam penelitian ini adalah Uji Kolmogorov-Smirnov. Suatu data dikatakan berdistribusi normal bila memiliki nilai signifikansi $>5 \%$ atau 0,05 .

\section{Uji Multikolinearitas}

Tujuan dari uji multikolinearitas adalah untuk mengetahui apakah terjadi korelasi pada suatu variabel independen. Uji regresi yang dinyatakan baik apabila data menunjukkan nilai $\mathrm{VIF}<10,00$ dan nilai tolerance $>0,100$ maka nilai tersebut 
dapat dinyatakan tidak memiliki gejala multikolinearitas.

\section{Koefisien Determinasi $\left(\mathbf{R}^{2}\right)$}

Koefisien determinasi adalah suatu pengukuran untuk mengetahui pengaruh yang diberikan variabel independen terhadap variabel dependen. Bila koefisien determinasi $\left(\mathrm{R}^{2}\right)$ semakin besar atau mendekati 1 maka bisa dinyatakan bahwa variabel independen mempunyai pengaruh besar terhadap variabel dependen.

\section{Pengujian Hipotesis Simultan (Uji F)}

Uji $F$ pada dasarnya bertujuan untuk melihat pengaruh dari seluruh variabel independen terhadap variabel dependen. Prosedur yang dapat digunakan adalah :

1. Taraf signifikansi pada penelitian ini adalah 0,05 dengan derajat bebas (n-k) yang mana $\mathrm{n}$ adalah julah pengamatan dan $\mathrm{k}$ adalah jumlah variabel.

2. Kriteria keputusan dapat dilakukan dengan: a) uji kecocokan ditolak jika $\mathrm{F}_{\text {hitung }}>\mathrm{F}_{\text {tabel }}$ atau sig $<\alpha$; b) uji kecocokan ditolak jika $\mathrm{F}_{\text {hitung }}<\mathrm{F}_{\text {tabel }}$ atau sig $>\alpha$

\section{Pengujian Hipotesis Simultan (Uji t)}

Uji t dilakukan untuk menguji koefisien regresi secara parsial, dimana pengujian ini bertujuan untuk mengetahui nilai signifikansi antara variabel independen terhadap variabel dependen. Penelitian ini menggunakan nilai signfikansi yaitu sebesar 0,05 dimana uji kecocokan ditolak jika nilai $t_{\text {hitung }}<\mathrm{t}_{\text {tabel }}$ (nilai sig $>\alpha$ ), dan uji kecocokan diterima jika nilai nilai $t_{\text {hitung }}>\mathrm{t}_{\text {tabel }}($ nilai $\operatorname{sig}<\alpha$ ).

\section{HASIL DAN PEMBAHASAN Analisis Regresi Berganda}

\begin{tabular}{|c|c|c|c|}
\hline Tabel & 2 Hasil Analisi & Regresi & Linear \\
\hline & \multirow{2}{*}{ Model } & \multicolumn{2}{|c|}{$\begin{array}{c}\text { Unstandardized } \\
\text { Coefficients }\end{array}$} \\
\hline & & B & Std. Error \\
\hline \multirow[t]{6}{*}{1} & (Constant) & -.426 & 3.927 \\
\hline & LN StrukturModal & -.171 & .115 \\
\hline & LN Likuiditas & .179 & .135 \\
\hline & LN_Profitabilitas & -.321 & .076 \\
\hline & LN_Dividen & .408 & .067 \\
\hline & $\begin{array}{l}\text { LN_UkuranPerusa } \\
\text { haan }\end{array}$ & .799 & 1.148 \\
\hline
\end{tabular}

Sumber : Data Olahan SPSS (2020)

Berdasarkan tabel 2 diatas, diperoleh model persamaan sebagai berikut:

LN_NilaiPerusahaan $=-0.426-0,171 \mathrm{LN} \_S t r u k t u r M o d a l$ $+0,179$ LN_Likuiditas - 0,321LN_Profitabilitas +

0,408LN_Dividen + 0,799LN_UkuranPerusahaan

Dimana :

1. Konstanta sebesar $-0,426$ jika variabel LN_StrukturModal (X1), LN_Likuiditas (X2), LN_Profitabilitas (X3), LN_Dividen (X)̄ , LN_UkuranPerusahaan (X5) dianggap nol, maka LN_NilaiPerusahaan (Y) pada Perusahaan Manufaktur di Bursa Efek Indonesia periode 2016 - 2019 ialah $-0,426$.

2. Koefisien regresi LN_StrukturModal (Debt to Equity Ratio) sebesar 0,171 memaparkan bahwa pada setiap kenaikan Debt to Equity Ratio satu kali, maka Price Earning Ratio menurun sebesar 0,171 .

3. Koefisien regresi LN_Likuiditas (Quick Ratio) sebesar 0,179 menyatakan bahwa setiap kenaikan Quick Ratio satu kali, maka Price Earning Ratio mengalami kenaikan 0,179 . 
4. Koefisien regresi LN_Profitabilitas (Return on Asset) sebesar -0,321 menyatakan setiap kenaikan Return on Asset satu kali, maka Price Earning Ratio menurun sebesar 0,321 .

5. Koefisien regresi LN_Dividen (Dividend Payout Ratio) sebesar 0,408 menyatakan setiap kenaikan Dividend Payout Ratio satu kali, maka Price Earning Ratio mengalami kenaikan sebesar 0,408.

6. Koefisien regresi LN_UkuranPerusahaan (Total Aset) sebesar 0,799 menyatakan bahwa setiap kenaikan Total Aset satu kali, maka Price Earning Ratio akan mengalami kenaikan sebesar 0,799.

\section{Koefisien Determinasi $\left(\mathbf{R}^{2}\right)$}

Tabel 3 Koefisien Determinasi

\begin{tabular}{llrr}
\hline $\begin{array}{l}\text { Mode } \\
1\end{array}$ & $\mathrm{R}$ & R Square & \multicolumn{1}{c}{$\begin{array}{c}\text { Adjusted R } \\
\text { Square }\end{array}$} \\
\hline 1 & $.516^{\mathrm{a}}$ & .266 & .243 \\
\hline
\end{tabular}

Sumber : Data Olahan SPSS (2020)

Tabel 3 mencantumkan nilai Adjusted $R^{2}$ sebesar 0,243 atau 24,3\% yang berarti variasi dari $Y$ dijelaskan oleh variabel Struktur Modal $\left(\mathrm{X}_{1}\right)$, Profitabilitas $\left(\mathrm{X}_{2}\right), \quad$ Likuiditas $\left(\mathrm{X}_{3}\right)$, Dividen $\left(\mathrm{X}_{4}\right)$, Ukuran Perusahaan $\left(\mathrm{X}_{5}\right)$ dan $75,7 \%$ sisanya dipengaruhi oleh variabel lain.

\section{Pengujian Hipotesis Simultan (Uji F)}

\begin{tabular}{cccc}
\multicolumn{4}{c}{ Tabel 4 Hasil Uji F } \\
\hline & Model & F & Sig. \\
\hline 1 & Regression & 11.684 & $.000^{\mathrm{b}}$ \\
\hline
\end{tabular}

Sumber : Data Olahan SPSS (2020)

Tabel 4 memaparkan $\mathrm{Df}_{1}$ (Jumlah variabel-1) $=5$ dan $\mathrm{Df}_{2}(\mathrm{n}-\mathrm{k}-1)=161(\mathrm{k}=$ jumlah variable, $\mathrm{n}=$ banyak data). Uji $\mathrm{F}$ didapatkan dari nilai $F_{\text {hitung }}$ sebesar 11,684 dengan nilai signifikannya 0,000 pada $F_{\text {tabel sebesar 2,268 dengan nilai }}$ signifikannya 0,05 . Maka $F_{\text {hitung }}(11,684)$ $>F_{\text {tabel }}(2,268)$ dengan nilai signifikan $0,00<0,05$, maka $\mathrm{H}_{0}$ ditolak dan $\mathrm{H}_{\mathrm{a}}$ diterima yang berarti variabel Struktur Modal, Likuiditas, Profitabilitas, Dividen, Ukuran Perusahaan memiliki pengaruh secara simultan terhadap Nilai Perusahaan pada Perusahaan Manufaktur yang terdaftar di Bursa Efek Indonesia periode 2016 - 2019.

\section{Pengujian Hipotesis Parsial (Uji t)}

Tabel 5 Hasil Uji t

\begin{tabular}{llrr}
\hline \multicolumn{1}{c}{ Model } & $\mathrm{t}$ & \multicolumn{1}{c}{ Sig. } \\
\hline \multirow{2}{*}{ (Constant) } & -.108 & .914 \\
\cline { 2 - 4 } & LN_StrukturModal & -1.484 & .140 \\
\cline { 2 - 4 } & LN_Likuiditas & 1.326 & .187 \\
\hline & LN_Profitabilitas & -4.206 & .000 \\
\cline { 2 - 4 } & LN_Dividen & 6.134 & .000 \\
\cline { 2 - 4 } & $\begin{array}{l}\text { LN_UkuranPerusa } \\
\text { haan }\end{array}$ & .696 & .487 \\
\hline Sumber
\end{tabular}

Sumber : Data Olahan SPSS (2020)

Dari tabel 5 diatas dapat dijelaskan hasil pengujian hipotesis secara parsial sebagai berikut:

1. Struktur Modal didapatkan $T_{\text {hitung }}$ 1,484 dengan nilai signifikan 0,000 sedangkan $\mathrm{T}_{\text {tabel }}$ sebesar $-1,974$ dengan nilai signifikan 0,05. Dapat disimpulkan $\mathrm{T}_{\text {hitung }}(-1,484)>\mathrm{T}_{\text {tabel }}(-$ $1,974)$ dengan nilai signifikan 0,140 $>0,05$ maka secara parsial variabel Struktur Modal tidak berpengaruh dan tidak signifikan terharap Nilai Perusahaan pada Perusahaan Manufaktur yang terdaftar di Bursa Efek Indonesia periode 2016 - 2019.

2. Likuiditas didapatkan $\mathrm{T}_{\text {hitung }} 1,326$ dengan nilai signifikan 0,000 sedangkan $T_{\text {tabel }}$ sebesar 1,974 dengan nilai signifikan 0,05 . 
Kesimpulannya $\mathrm{T}_{\text {hitung }} 1,326<\mathrm{T}_{\text {tabel }}$ 1,974 dengan nilai signifikan $0,187>$ 0,05 maka secara parsial variabel Likuiditas tidak berpengaruh dan tidak signifikan terharap Nilai Perusahaan pada Perusahaan Manufaktur yang terdaftar di Bursa Efek Indonesia periode 2016 - 2019.

3. Profitabilitas didapatkan $\mathrm{T}_{\text {hitung }}$ 4,206 dengan nilai signifikan 0,000 sedangkan $\mathrm{T}_{\text {tabel }}$ sebesar $-1,974$ dengan nilai signifikan 0,05 . Kesimpulannya $T_{\text {hitung }}(-4,206)<$ $\mathrm{T}_{\text {tabel }}(-1,974)$ dengan nilai signifikan $0,00<0,05$ maka secara parsial variabel Profitabilitas berpengaruh negatif dan signifikan terharap Nilai Perusahaan pada Perusahaan Manufaktur yang terdaftar di Bursa Efek Indonesia periode 2016 - 2019.

4. Dividen didapatkan $\mathrm{T}_{\text {hitung }} 6,134$ dengan nilai signifikan 0,000 sedangkan $\mathrm{T}_{\text {tabel }}$ sebesar 1,974 dengan nilai signifikan 0,05 . Kesimpulannya $\mathrm{T}_{\text {hitung }} 6,134>\mathrm{T}_{\text {tabel }}$ 1,974 dengan nilai signifikan $0,00<$ 0,05 maka secara parsial variabel Dividen berpengaruh positif dan signifikan terharap Nilai Perusahaan pada Perusahaan Manufaktur yang terdaftar di Bursa Efek Indonesia periode 2016 - 2019.

5. Ukuran Perusahaan didapatkan $T_{\text {hitung }}$ 0,696 dengan nilai signifikan 0,000 sedangkan $\mathrm{T}_{\text {tabel }}$ sebesar 1,974 dengan nilai signifikan 0,05 . Kesimpulannya $\mathrm{T}_{\text {hitung }} 0,696<\mathrm{T}_{\text {tabel }}$ 1,974 dengan nilai signifikan $0,487>$ 0,05 maka secara parsial variabel Ukuran Perusahaan tidak berpengaruh dan tidak signifikan terharap Nilai Perusahaan pada Perusahaan Manufaktur yang terdaftar di Bursa Efek Indonesia periode 2016 - 2019 .

\section{Pengaruh Struktur Modal terhadap Nilai Perusahaan}

Berdasarkan hasil Uji $\mathrm{T}$ maka disimpulkan bahwa Struktur Modal tidak berpengaruh dan tidak signifikan terhadap Nilai Perusahaan pada Perusahaan Manufaktur periode 2016 - 2019. Hasil tersebut sepaham dengan penelitian Lubis, et.al (2017) yang menyatakan Struktur Modal tidak berpengaruh dan tidak signifikan terhadap Nilai Perusahaan. Namun hasil penelitian ini bertentangan dengan penelitian Permatasari, et.al. (2018) yang menyatakan Struktur Modal berpengaruh positif dan signifikan terhadap Nilai Perusahaan.

\section{Pengaruh Likuiditas terhadap Nilai Perusahaan}

Berdasarkan hasil Uji $\mathrm{T}$ maka disimpulkan bahwa Likuiditas tidak berpengaruh dan tidak signifikan terhadap Nilai Perusahaan pada Perusahaan Manufaktur periode 2016 - 2019. Hasil ini sepaham dengan penelitian Sudiani, et.al. (2016) yang menyatakan Likuiditas tidak berpengaruh dan tidak signifikan terhadap Nilai Perusahaan. Namun hasil penelitian ini bertentangan dengan penelitian Wijaya, et.al (2014) yang menyatakan Likuiditas berpengaruh positif dan signifikan terhadap nilai perusahaan.

\section{Pengaruh Profitabilitas terhadap Nilai Perusahaan}

Berdasarkan hasil Uji $\mathrm{T}$ dapat disimpulkan bahwa Profitabilitas berpengaruh negatif dan signifikan terhadap Nilai Perusahaan pada Perusahaan Manufaktur periode 2016 2019. Hasil ini sepaham dengan penelitian Pratama \& Wiksuana (2018) yang menyatakan Profitabilitas berpengaruh negatif terhadap Nilai 
Perusahaan. Namun hasil ini bertentangan dengan penelitian Tarima Grandy, Parengkuan Ramdhonah \& Sari (2019) yang menyatakan Profitabilitas tidak berpengaruh dan tidak signifikan terhadap Nilai Perusahaan.

\section{Pengaruh Dividen terhadap Nilai Perusahaan}

Berdasarkan hasil uji Uji T dapat disimpulkan bahwa Dividen berpengaruh positif dan signifikan terhadap Nilai Perusahaan pada Perusahaan Manufaktur periode 2016 - 2019. Hasil ini sepaham dengan penelitian Yadnyana \& Wati (2011) yang menyatakan Dividen berpengaruh positif dan signifikan terhadap Nilai Perusahaan. Namun hasil ini bertentangan dengan penelitian Anita \& Yulianto (2016) yang menyatakan Dividen tidak berpengaruh dan tidak signifikan terhadap Nilai Perusahaan.

\section{Pengaruh Ukuran Perusahaan terhadap Nilai Perusahaan}

Berdasarkan hasil uji Uji T dapat disimpulkan bahwa Ukuran Perusahaan tidak berpengaruh dan tidak signifikan terhadap Nilai Perusahaan pada Perusahaan Manufaktur periode 2016 2019. Hasil ini sepaham dengan penelitian Wijaya, et.al (2018) yang menyatakan bahwa Ukuran Perusahaan tidak berpengaruh dan tidak signifikan terhadap Nilai Perusahaan .Namun hasil ini bertentangan dengan penelitian Lumoly et.al. (2018) yang menyatakan Ukuran Perusahaan berpengaruh positif dan signifikan terhadap Nilai Perusahaan.

\section{PENUTUP}

\section{Kesimpulan}

Berdasarkan hasil penelitian diatas, dapat disimpulkan bahwa :

1. Pengaruh Struktur Modal secara parsial tidak berpengaruh dan tidak signifikan terhadap Nilai Perusahaan pada Perusahaan Manufaktur yang terdaftar di Bursa Efek Indonesia tahun 2016-2019.

2. Pengaruh Likuiditas secara parsial tidak berpengaruh dan tidak signifikan terhadap Nilai Perusahaan pada Perusahaan Manufaktur yang terdaftar di Bursa Efek Indonesia tahun 2016-2019.

3. Pengaruh Profitabilitas secara parsial berpengaruh negatif dan signifikan terhadap Nilai Perusahaan pada Perusahaan Manufaktur yang terdaftar di Bursa Efek Indonesia tahun 2016-2019.

4. Pengaruh Dividen secara parsial berpengaruh positif dan signifikan terhadap Nilai Perusahaan pada Perusahaan Manufaktur yang terdaftar di Bursa Efek Indonesia tahun 2016-2019.

5. Pengaruh Ukuran Perusahaan secara parsial tidak berpengaruh dan tidak signifikan terhadap Nilai Perusahaan pada Perusahaan Manufaktur yang terdaftar di Bursa Efek Indonesia tahun 2016-2019.

\section{Saran}

Berdasarkan penelitan yang kami lakukan maka terdapat beberapa saran seperti dibawah ini :

1. Bagi Investor dan Calon Investor. Investor sebaiknya memperhatikan variabel Return on Assets, Quick Ratio, Dividend Payout Ratio, Debt to Equity Ratio, Price Earning Ratio sebelum melakukan investasi di suatu perusahaan.

2. Bagi Universitas Prima Indonesia. Diharapkan dapat menjadi kontributor dalam pengembangan teori mengenai Return on Assets, Quick Ratio, Dividend Payout Ratio, 
Devt to Equity Ratio, Price Earning Ratio.

3. Bagi Peneliti Selanjutnya. Diharapkan untuk menambahkan rasio lain sebagai variabel seperti Leverage dan Keputusan Investasi yang mungkin dapat mempengaruhi Nilai Perusahaan.

\section{DAFTAR PUSTAKA}

Anita, A \& Yulianto, A. (2016). Pengaruh Kepemilikan Manajerial dan Kebijakan Dividen terhadap Nilai Perusahaan. Management Analysis Journal. 5(1).

Antari, D. A. P. P., \& Dana, I. M. (2013). Pengaruh struktur modal, kepemilikan manajerial, dan kinerja keuangan terhadap nilai perusahaan. E- Jurnal Manajemen, 2(3).

Lubis, I., L \& Sinaga, B., M \& Sasongko, H. (2017). Pengaruh Profitabilitas, Struktur Modal, dan Likuiditas Terhadap Nilai Perusahaan. Jurnal Aplikasi Bisnis dan Manajemen, 3(3).

Lumoly, S \& Murni, S \& Untu. V.,N. (2018). Pengaruh Likuiditas, Ukuran Perusahaan dan Profitabilitas terhadap Nilai Perusahaan. Jurnal EMBA. 6(3).

Putra, A., A., N \& Lestari, P.,V. (2016). Pengaruh Kebijakan Dividen, Likuiditas, Profitabilitas dan Ukuran Perusahaan Terhadap Nilai Perusahaan. E-Jurnal Manajemen Unud, 5(7).

Permatasari, D \& Azizah D., F. (2018). Pengaruh Struktur Modal Terhadap Nilai Perusahaan (Studi Pada Perusahaan Sub Sektor Makanan dan Minuman Yang Terdaftar di Bursa Efek Indonesia Tahun 2013-2016). Jurnal Administrasi Bisnis. 61(4).
Pratama, A \& Wiksuana. (2018). Pengaruh Firm Size dan Profitabilitas terhadap Nilai Perusahaan dengan Struktur Modal Sebagai Variabel Mediasi. E-Jurnal Ekonomi dan Bisnis Universitas Udayana. 7(5).

Ramdhonah, Z, Solikin, I. \& Sari, M. (2019). Pengaruh Struktur Modal, Ukuran Perusahaan, Pertumbuhan Perusahaan, dan Profitabilitas terhadap Nilai Perusahaan. Jurnal Riset Akuntansi dan Keuangan. 7(1).

Sudiani, N., K., A \& Darmayanti, N, P., A. (2016). Pengaruh Profitabilitas, Likuiditas, Pertumbuhan, dan Investment Opportunity Set terhadap Nilai Perusahaan. EJurnal Manajemen Unud, 5(7).

Thaib, I \& Dewantoro, A. (2017), Pengaruh Profitabilitas dan Likuiditas Terhadap Nilai Peruahaan Dengan Struktur Modal Sebagai Variabel Intervening. Jurnal Riset Perbankan Manajemen dan Akuntans, 1(1).

Wijaya, I., B., N \& Purnawati, N., K. (2014). Pengaruh Likuiditas dan Kepemilikan Institusional Terhadap Nilai Perusahaan Dimoderasi oleh Kebijakan Dividen.

Wijaya, B., I \& Sedana, I., B., P. (2018). Pengaruh Profitabilitas Terhadap Nilai Perusahaan (Kebijakan Dividen dan Kesempatan Investasi Sebagai Variabel Mediasi). EJurnal Manajemen Unud, 4(12). E-Jurnal Manajemen. 3(12)

Yadyana, K \& Wati. (2011). Struktur Kepemilikan, Kebijakan Dividen, dan Nilai Perusahaan Manufaktur yang Go Public. Jurnal Keuangan dan Pebankan. 15(1). 